\title{
Deoxyribonucleic Acid Reassociation Experiments with a Halophilic, Lactose-Fermenting Vibrio Isolated from Blood Cultures
}

\author{
WILLIAM A. CLARK AND ARNOLD G. STEIGERWALT \\ Center for Disease Control, Atlanta, Georgia 30333
}

\begin{abstract}
Hollis et al. (J. Clin. Microbiol. 3:425-431, 1976) recently described an apparently new group of bacteria, with characteristics of the genus Vibrio, which was isolated from human blood, spinal fluid, and local infections of the extremities, and which caused fatal fulminant septicemia in at least 5 of 38 cases. The organisms were morphologically and biochemically similar to, but not identical with, both Vibrio alginolyticus and $V$. parahaemolyticus; they had different isolation sources from those of the latter two species, and they also fermented lactose and possessed different tolerances for sodium chloride in nutrient broth. This paper reports the results of deoxyribonucleic acid (DNA) reasociation experiments, which showed that DNA fragments from six strains of the newly described organisms, incubated at $60^{\circ} \mathrm{C}$ with DNA fragments from $V$. alginolyticus, V. cholerae, and V. parahaemolyticus, resulted in DNA duplex formation showing a level of relatedness consistent with that of different species within a genus. All strains of the newly described vibrio were highly related. Incubation at $75^{\circ} \mathrm{C}$ produced less than $10 \%$ relative duplex formation. When tested for heat stability, these duplexes had low temperatures of dissociation, indicating imperfectly matched DNA molecules. We thus concluded that the newly described vibrio is a species distinct from the other species studied.
\end{abstract}

Recently Hollis et al. (5) described a halophilic vibrio capable of causing fatal septicemia which was isolated chiefly from human blood, spinal fluid, and localized infections of the extremities. The organism differed from Vibrio parahaemolyticus in its ability to ferment lactose and in its lower tolerance for sodium chloride in nutrient broth. In addition, it differed from $V$. alginolyticus in its failure to ferment sucrose and to produce acetylmethylcarbinol. Its isolation sources were also different from those of the latter two vibrios. In their study, they referred to this organism as the lactosepositive $(\mathrm{L}+)$ Vibrio.

We describe deoxyribonucleic acid (DNA) reassociation experiments with strains of this recently characterized vibrio and of other vibrios. Results indicate the $(\mathrm{L}+)$ Vibrio is indeed a different species, possessing the minimal morphological and biochemical characteristics of the genus (6), but distinct from other species of Vibrio.

\section{MATERIALS AND METHODS}

Cultures. We chose the $V$. alginolyticus, $V$. parahaemolyticus, and $(\mathrm{L}+)$ Vibrio cultures from which the DNAs were prepared from the culture collection of the Special Bacteriology Section, Center for Disease Control, Atlanta, Ga. This culture collection is maintained frozen in defibrinated rabbit blood at $-55^{\circ} \mathrm{C}$. Table 1 provides a list of cultures used, and gives their different sources of isolation from various geographic areas.

After the culture was thawed, a droplet was streaked on rabbit blood agar and incubated in a candle jar at $35^{\circ} \mathrm{C}$ for 18 to $24 \mathrm{~h}$. We prepared working stocks by subculturing from blood agar into motility medium (formula given below), incubating at $25^{\circ} \mathrm{C}$ until they were well grown, and then maintaining them at room temperature (about $25^{\circ} \mathrm{C}$ ) in corked test tubes. These cultures remained viable for months.

Culture media. Rabbit blood agar, i.e., $5 \%$ sterile, defibrinated rabbit blood in heart infusion agar (Difco), was used to propagate thawed bacteria.

Motility medium ( $16 \mathrm{~g}$ of motility test medium [Difco], $4 \mathrm{~g}$ of nutrient broth [Difco], $1 \mathrm{~g}$ of NaCl, and 1 liter of distilled water) was used for maintaining working stock cultures for the experiments. This medium was dispensed as soft agar deeps, $8 \mathrm{ml}$ per 15-by-125-mm tube.

Brain heart infusion broth (BHI; Difco) was used to propagate the cultures for unlabeled DNA preparation.

We modified Citarella and Colwell's medium (4) by substituting acid-hydrolyzed casein for salt- and vitamin-free casein hydrolysate, and used it to grow the culture A8694 of $(\mathrm{L}+)$ Vibrio for preparation of radiolabeled DNA. Our medium consisted of the following: $\mathrm{NaCl}, 24.0 \mathrm{~g}$; KCl, $0.017 \mathrm{~g} ; \mathrm{MgCl}_{2} \cdot 6 \mathrm{H}_{2} \mathrm{O}$, $5.3 \mathrm{~g}$; tris(hydroxymethyl)aminomethane (Tris), 
TABLE 1. Bacterial strains

\begin{tabular}{lll}
\hline \multicolumn{1}{c}{ Species } & \multicolumn{1}{c}{ Strain } & \multicolumn{1}{c}{ Source $^{a}$} \\
\hline Serratia marcescens & SM-6 & D. J. Brenner, CDC \\
Vibrio alginolyticus & ATCC 17749 (type culture) & ATCC \\
Vibrio alginolyticus & CDC-C6814 & Leg wound (Georgia) \\
Vibrio cholerae & CDC-5540-70 & Stool (Dacha) \\
Vibrio cholerae (El Tor) & CDC-1320-72 & Stool (Algeria) \\
Vibrio cholerae (non-agglutinating) & CDC-1845-73 & Stool (Texas) \\
Vibrio parahaemolyticus & ATCC 17802 (type culture) & ATCC \\
Vibrio parahaemolyticus & CDC-A8633 & Ear (New York) \\
(L+) Vibrio & CDC-A1402 & Corneal ulcer (Virginia) \\
(L+) Vibrio & CDC-A8694 & Blood (Florida) \\
(L+) Vibrio & CDC-B3547 & Leg wound (Rhode Island) \\
(L+) Vibrio & CDC-C7127 & Blood (California) \\
(L+) Vibrio & CDC-C7684 & Thumb drainage (Texas) \\
(L+) Vibrio & CDC-C8806 & Blood (Texas) \\
Yersinia ruckeri (red mouth bacterium) & $4535-69$ & D. J. Brenner, CDC \\
\hline
\end{tabular}
Md.

a CDC, Center for Disease Control, Atlanta, Ga.; ATCC, American Type Culture Collection, Rockville,

$12.1 \mathrm{~g}$; casein hydrolysate (acid) (Nutritional Biochemicals Corp.), 0.5 g; glucose, $5 \mathrm{~g}$; BHI broth, $4 \mathrm{ml}$; carrier-free $\mathrm{H}_{3}{ }^{32} \mathrm{PO}_{4}$ (New England Nuclear Corp.), $10 \mu \mathrm{Ci} / \mathrm{ml}$; distilled water, 1 liter; $\mathrm{pH}$ adjusted to 8.0 with $\mathrm{HCl}$.

Reagents. The reagents used included the following: (i) lysing solution: ethylenediaminetetraacetate, $0.05 \mathrm{M}$; Tris, $0.05 \mathrm{M}$; $\mathrm{NaCl}, 0.1 \mathrm{M}$; Pronase (Calbiochem), $50 \mu \mathrm{g} / \mathrm{ml}$; (ii) phosphate buffer (PB): an equimolar mixture of monobasic and dibasic potassium phosphate, $\mathrm{pH} 6.8$; (iii) liquefied phenol: Mallinkrodt analytical reagent, $88 \%$; (iv) bovine pancreatic ribonuclease (Calbiochem): heated to 80 to $90^{\circ} \mathrm{C}$ for $10 \mathrm{~min}$ to inactivate any contaminating deoxyribonuclease; (v) Pronase (Calbiochem); (vi) ethoxyethanol (Fisher Cellosolve, purified); (vii) scintillation fluid: Econofluor (New England Nuclear Corp., Boston, Mass.); (viii) calf thymus DNA carrier (Sigma Chemical Co., St. Louis, Mo.); (ix) ${ }^{32} \mathrm{PO}_{4}$ (New England Nuclear Corp., Boston, Mass.); (x) sodium dodecyl sulfate (SDS) (BDH Chemicals, Ltd., Poole, England); and (xi) hydroxyapatite (HA), DNA grade (BioRad Laboratories, Richmond, Calif.).

Preparation of unlabeled DNA. The following is a brief description of the procedure which Brenner et al. (2) discussed in detail. The stock culture was inoculated into $20 \mathrm{ml}$ of $\mathrm{BHI}$ broth and incubated at $37^{\circ} \mathrm{C}$ on a New Brunswick rotary shaker (model G25, New Brunswick Scientific Co., New Brunswick, N.J.). The total culture was transferred to 1.5 liters of BHI broth and incubated on the shaker at $37^{\circ} \mathrm{C}$ for $16 \mathrm{~h}$. The cells were sedimented in a refrigerated centrifuge (model RC-3, Ivan J. Sorvall, Norwalk, Conn.) and suspended into $100 \mathrm{ml}$ of lysing solution. SDS was added to a concentration of $0.5 \%$, and the bacteria were lysed in a $37^{\circ} \mathrm{C}$ water bath for $10 \mathrm{~min}$. After the cell protein was extracted with $100 \mathrm{ml}$ of phenol, the mixture was shaken for $1 \mathrm{~min}$ and then centrifuged at 3,000 rpm in a Sorvall model SS-3 centrifuge to separate the aqueous layer containing DNA. The DNA solution was made $1 \mathrm{M}$ with sodium perchlorate. After residual phenol was extracted with $100 \mathrm{ml}$ of chloroform, the mixture was centrifuged to separate the aqueous DNA layer. The extraction was repeated. The DNA was precipitated with $200 \mathrm{ml}$ of cold, absolute ethyl alcohol, and the precipitate was spooled. The DNA was dissolved in $25 \mathrm{ml}$ of distilled water and 2 drops of chloroform. After the initial ethanol precipitation of DNA, the procedure was repeated twice, each time insuring that the solution was $0.1 \mathrm{M}$ with $\mathrm{NaCl}$. Lysing solution was added to a total volume of $100 \mathrm{ml}$; contaminating RNA was removed with ribonuclease $(50 \mu \mathrm{g} /$ $\mathrm{ml})$ at $37^{\circ} \mathrm{C}$ for $1 \mathrm{~h}$. Ribonuclease and contaminating byproducts were removed with Pronase $(50 \mu \mathrm{g} / \mathrm{ml})$ and $0.5 \%$ SDS at $37^{\circ} \mathrm{C}$ for $1 \mathrm{~h}$. Residual Pronase was extracted with an equal volume of phenol, and the aqueous DNA layer was separated by centrifugation. Residual phenol was extracted with chloroform twice. The DNA was precipitated three times with ethoxyethanol, each time insuring that the solution was $0.1 \mathrm{M}$ with $\mathrm{NaCl}$. The DNA was made $0.28 \mathrm{M}$ with PB. It was then sonically extracted with a Branson Sonifier (Heat Systems, Ultrasonics, Inc., Plainview, N.Y.) at an energy level of 4 for 1.5 to 3 min. The DNA content of the sample was determined with a Beckman spectrophotometer (model Acta III, Beckman Instruments, Inc., Fullerton, Calif.). The DNA solution was stored with 2 drops of chloroform at $4^{\circ} \mathrm{C}$.

D. J. Brenner prepared DNAs from Vibrio cholerae, Serratia marcescens, and Yersinia ruckeri (red mouth bacterium) strains and contributed them for these experiments.

Preparation of ${ }^{32} \mathrm{P}$-labeled DNA. The stock culture of $(\mathrm{L}+)$ Vibrio strain A8694 was subcultured into $50 \mathrm{ml}$ of $\mathrm{BHI}$ broth and incubated for $8 \mathrm{~h}$ on a rotary shaker at $37^{\circ} \mathrm{C}$. The resulting culture was transferred into 1.5 liters of the modified CitarellaColwell medium, without phosphate, and incubated for $1 \mathrm{~h}$ at $37^{\circ} \mathrm{C}$ with shaking. A $10-\mathrm{mCi}$ amount of ${ }^{32} \mathrm{P}$ was added to the culture, which was then reincubated with shaking for an additional $16 \mathrm{~h}$. The culture was centrifuged and the labeled DNA was extracted by using the same procedure described 
above, except that only $20 \mathrm{ml}$ of lysing solution was added to the sedimented cells, insuring a high concentration of DNA.

After it was purified and sheared, the labeled DNA was denatured at $100^{\circ} \mathrm{C}$ for $4 \mathrm{~min}$, chilled at $0^{\circ} \mathrm{C}$ (quenched), passed through an HA column equilibrated with $0.14 \mathrm{M}$ PB plus $0.4 \%$ SDS, and held at $60^{\circ} \mathrm{C}$. DNA bound to the column was discarded. This procedure reduced the "zero-time binding" (label bound to the column immediately after DNA has been denatured). Recovered singlestranded DNA fragments were stored at $4^{\circ} \mathrm{C}$ with chloroform.

DNA reassociation. Thermally denatured, labeled DNA fragments $(0.1 \mu \mathrm{g} / \mathrm{ml})$ were incubated at 60 or $75^{\circ} \mathrm{C}$ with a 1,500 -fold excess of denatured, unlabeled DNA fragments in $0.28 \mathrm{M}$ PB for $16 \mathrm{~h}$. After the incubation procedure was completed, the buffer concentration was diluted to $0.14 \mathrm{M}$, and the DNA mixture was passed through $\mathrm{HA}$ to separate single-stranded DNA by the batch procedure of Brenner et al. (3). HA was equilibrated with $0.14 \mathrm{M}$ $\mathrm{PB}$ plus $0.4 \%$ SDS and held at 60 or $75^{\circ} \mathrm{C}$. Four $15-\mathrm{ml}$ portions of $0.14 \mathrm{M} \mathrm{PB}$ plus SDS at the incubation temperature removed unreassociated DNA. HA then was washed with four $15-\mathrm{ml}$ portions of $0.4 \mathrm{M}$ $\mathrm{PB}$, the salt concentration at which the reassociated, double-stranded DNA was removed from the HA. All eluates (except those from reassociation experiments in which tritium-labeled DNA from the non-agglutinating $V$. cholerae strain $1845-73$ was used) were collected in counting vials for assay. Tritiated samples were precipitated in 5\% trichloroacetic acid in the presence of approximately $100 \mu \mathrm{g}$ of calf thymus DNA carrier. The precipitates were collected on membrane filters (pore size $0.45 \mu \mathrm{m}$ ) (Millipore Corp., Bedford, Mass.), placed in counting vials, and dried in a hot-air oven at $60^{\circ} \mathrm{C}$. A 15 ml volume scintillation fluid was added to each sample prior to assay. Radioactivity was assayed in a Packard liquid scintillation spectrometer (model 2450, Packard Instruments, Downers Grove, Ill.).

Determination of approximate base composition from thermal elution temperatures. Thermal elution experiments were carried out with sufficient (10 $\mathrm{ml}$ per tube) HA to adsorb $2 \mathrm{mg}$ of native DNA added to the column for each sample. The temperature of the water bath holding the HA columns was increased in $5^{\circ} \mathrm{C}$ increments from 60 to $80^{\circ} \mathrm{C}$, and thereafter in $2^{\circ} \mathrm{C}$ increments from 80 to $100^{\circ} \mathrm{C}$. At each temperature the HA column was washed with one $10-\mathrm{ml}$ portion of $0.14 \mathrm{M} \mathrm{PB}$. After the $100^{\circ} \mathrm{C}$ portion had been collected, the sample was given a final wash with $0.4 \mathrm{M} \mathrm{PB}$. To determine the amount of DNA eluted from HA, the optical density of each wash was determined with the spectrophotometer at wavelengths of $258 \mathrm{~nm}$ and $300 \mathrm{~nm}$. The temperature at which half of the adsorbed DNA was eluted from HA was taken to be the approximate thermal denaturation temperature $\left(T_{m(e)}\right)$. The formula of Marmur and Doty, $T_{m}=69.3+0.41$ (guanine plus cytosine $[G+C])(9)$, was used to determine the approximate $\mathrm{G}+\mathrm{C}$ base composition. DNA preparations from $S$. marcescens and $Y$. ruckeri were used as standards.

\section{RESULTS}

Table 2 shows the degree of reassociation that occurred when radioactive ${ }^{32} \mathrm{P}$-labeled DNA fragments from (L+) Vibrio strain A8694 were incubated with unlabeled DNA fragments from the same strain, from other strains of $(\mathrm{L}+)$ Vibrio, and from $V$. alginolyticus, $V$. cholerae, and $V$. parahaemolyticus at two incubation temperatures $\left(60^{\circ} \mathrm{C}\right.$, optimal for reassociation, and $75^{\circ} \mathrm{C}$, where only highly related DNA duplexes are stable). The degree of reassociation (relative binding) among labeled DNA from strain A8694 and unlabeled DNA from other strains of the same species was between 85 and $93 \%$ at $60^{\circ} \mathrm{C}$, and between 82 and $92 \%$ at $75^{\circ} \mathrm{C}$.

Strain A8694 exhibited 25 to $46 \%$ relative binding with $V$. alginolyticus, 15 to $32 \%$ with $V$. cholerae, and 41 to $48 \%$ with $V$. parahaemolyticus at $60^{\circ} \mathrm{C}$.

At the more stringent $75^{\circ} \mathrm{C}$ incubation, less than $10 \%$ reassociation occurred among DNA from $(\mathrm{L}+)$ Vibrio and DNA from all other species tested.

Table 2 also includes results obtained at $60^{\circ} \mathrm{C}$ with ${ }^{3} \mathrm{H}$-labeled DNA (supplied by D. J. Brenner) from $V$. cholerae (non-agglutinating) strain 1845-73. The $(\mathrm{L}+)$ Vibrio strains were 22 to $37 \%$ related to strain $1845-73$. $V$. alginolyticus showed 40 to $45 \%$ binding, V. parahaemolyticus showed 46 to $56 \%$ binding, and $V$. cholerae showed 85 to $86 \%$ binding.

Thermal stability of reassociated DNA fragments formed at various incubation temperatures is an index of the extent and specificity of base pairing. Bautz (1) estimated that the presence of approximately $1 \%$ unpaired bases within a reassociated polynucleotide fragment lowers its thermal stability by $1^{\circ} \mathrm{C}$. After radioactive ${ }^{32} \mathrm{P}$-labeled DNA fragments of $(\mathrm{L}+) \mathrm{Vi}$ brio $\mathrm{A} 8694$ were incubated overnight at $60^{\circ} \mathrm{C}$ with unlabeled DNA fragments from other strains of $(\mathrm{L}+)$ Vibrio, V. alginolyticus, $V$. cholerae, and $V$. parahaemolyticus, the thermal stability of the reassociated DNA duplexes was tested (Table 3).

The $T_{m(e)}$ of homologous A8694 DNA was about $92.5^{\circ} \mathrm{C}$ (the range was 90.3 to $93.8^{\circ} \mathrm{C}$ for six trials). The elution temperatures of reassociated DNA from reactions between DNA fragments of A8694 (labeled) and other (L+) Vibrio strains all are in the range of 89.7 to $93.3^{\circ} \mathrm{C}$. The decrease in thermal elution temperature for heteroduplexes formed ranges from 0.2 to $3.2^{\circ} \mathrm{C}$. Thus it appears that those polynucleotide sequences shared in common among various strains of $(\mathrm{L}+)$ Vibrio are highly similar.

On the other hand, the elution temperatures 
TABLE 2. Reassociation among DNA fragments from Vibrio sp. (lactose positive) and from other Vibrio strains ${ }^{a}$

\begin{tabular}{|c|c|c|c|}
\hline \multirow{3}{*}{ Source of unlabeled DNA } & \multicolumn{3}{|c|}{$\%$ Binding } \\
\hline & \multicolumn{2}{|c|}{$(\mathrm{L}+)$ Vibrio $\mathrm{A} 8694^{b}$} & \multirow{2}{*}{$\begin{array}{l}\text { Vibrio cholerae (non-aggl) } \\
-\quad 1845-73^{b} ; 60^{\circ} \mathrm{C}\end{array}$} \\
\hline & $60^{\circ} \mathrm{C}$ & $75^{\circ} \mathrm{C}$ & \\
\hline$(\mathrm{L}+)$ Vibrio A8694 & $100^{c}$ & $100^{d}$ & 37 \\
\hline$(\mathrm{L}+)$ Vibrio A1402 & 90 & 82 & 24 \\
\hline$(\mathrm{L}+)$ Vibrio B3547 & 85 & 83 & 25 \\
\hline$(\mathrm{L}+)$ Vibrio $\mathrm{C} 7127$ & 93 & 86 & 22 \\
\hline$(\mathrm{L}+)$ Vibrio $\mathrm{C} 7684$ & 87 & 92 & 22 \\
\hline$(\mathrm{L}+)$ Vibrio $\mathrm{C} 8806$ & 87 & 83 & 26 \\
\hline Vibrio alginolyticus ATCC 17749 & 25 & 6 & 40 \\
\hline Vibrio alginolyticus $\mathrm{C} 6814$ & 46 & 7 & 45 \\
\hline Vibrio parahaemolyticus ATCC 17802 & 48 & 8 & 56 \\
\hline Vibrio parahaemolyticus A8633 & 41 & 1 & 46 \\
\hline Vibrio cholerae $5540-70$ & 16 & 0 & 85 \\
\hline Vibrio cholerae (El Tor) $1320-72$ & 15 & 0 & 86 \\
\hline Vibrio cholerae (non-aggl) 1845-73 & 32 & 4 & $100^{e}$ \\
\hline
\end{tabular}

${ }^{a}$ Each reaction was done three or four times at $60^{\circ} \mathrm{C}$ and twice at $75^{\circ} \mathrm{C}$.

${ }^{b}$ Source of labeled DNA.

$c, d, e$ Average binding before normalization was $(c) 82 \% ;(d) 87 \%$; $(e) 78 \%$.

of reassociated DNA fragments from reactions among (L+) Vibrio A8694 (labeled) and V. alginolyticus, $V$. cholerae, and $V$. parahaemolyticus are considerably lower $\left(71\right.$ to $\left.78^{\circ} \mathrm{C}\right)$, indicating a higher percentage of unpaired bases.

Marmur and Doty (7) showed that heating DNA in solution produced an increase in its extinction coefficient at the temperature at which the DNA becomes denatured. The midpoint temperature of the absorbance rise is linearly related to the average DNA base composition; a higher $\mathrm{G}+\mathrm{C}$ content confers a higher thermal stability.

The $T_{m(e)}$ of native DNA from six strains of $(\mathrm{L}+)$ Vibrio was determined as described in Materials and Methods in order to find the approximate $\mathrm{G}+\mathrm{C}$ content in those organisms. Marmur and Doty's formula (8) was used to calculate the base composition of the DNA. The $\mathrm{G}+\mathrm{C}$ content determined ranged from 49.8 to $53.4 \mathrm{~mol} \%$, with an average of $51.0 \mathrm{~mol} \%$ for the six strains.

\section{DISCUSSION}

Hollis and co-workers stated (5) that $(\mathrm{L}+)$ Vibrio not only showed biochemical characteristics which distinguished it from $V$. parahaemolyticus and $V$. alginolyticus, but also pointed out that the sources of these organisms and illnesses caused by them were different. $(\mathrm{L}+)$ Vibrio was isolated from blood, local infections, and spinal fluid, and appeared more likely to produce localized infections or systemic illnesses; 2 of 60 strains of $V$. alginolyticus and $V$. parahaemolyticus from extraintes- tinal sources were isolated from blood. In contrast, $V$. alginolyticus has been implicated in wound infections (10), whereas $V$. parahaemolyticus usually causes gastroenteritis. Hollis et al. suggested that the lactose-positive vibrios should be regarded either as a subspecies of $V$. parahaemolyticus or as a possibly new, distinct species.

The genetic evidence presented here indicates that these organisms belong to a species different from $V$. parahaemolyticus, $V$. alginolyticus, and $V$. cholerae. Brenner et al. (2) showed that, in most cases in the family Enterobacteriaceae, interspecies duplex formation is $55 \%$ or less, whereas that obtained from intraspecies DNA reassociation is $70 \%$ or greater. Extrapolating to other bacterial families, we can say that we were dealing with interspecies relationships among the vibrios we tested, because the degree of DNA homology at $75^{\circ} \mathrm{C}$ incubation among the newly described group and the three known species tested was always less than $10 \%$.

The homology values of DNA from the various strains of $(\mathrm{L}+)$ Vibrio reassociated at 60 and $75^{\circ} \mathrm{C}$ were very close, indicating a precise relationship among the sequences of the reassociated strands (Table 2). With $60^{\circ} \mathrm{C}$ incubation, relative homology between the new species and any one of the other named species mentioned drops to $50 \%$ or lower; at the more stringent $75^{\circ} \mathrm{C}$ incubation, the homology values drop below $10 \%$. Undoubtedly in $(\mathrm{L}+)$ Vibrio we are dealing with a distinct species of Vibrio.

Although the six strains of $(\mathrm{L}+)$ Vibrio 
TABLE 3. Thermal elution midpoints $\left(T_{m(e)}\right)$ of reassociated $D N A$ fragments from $(L+)$ Vibrio and from other Vibrio species bound to hydroxyapatite at $60^{\circ} \mathrm{C}$ incubation

\begin{tabular}{|c|c|c|c|}
\hline Nucleic acid reaction & $T_{m(e)}$ & $\Delta T_{m(e)}$ & $\begin{array}{c}\text { Relative binding } \\
(\%)\end{array}$ \\
\hline$\frac{(\mathrm{L}+) \text { Vibrio } \mathrm{A} 8694}{(\mathrm{~L}+) \text { Vibrio } \mathrm{A} 8694}$ & 92.5 & & 100 \\
\hline$\frac{(\mathrm{L}+) \text { Vibrio } \mathrm{A} 8694}{(\mathrm{~L}+) \text { Vibrio } \mathrm{A} 1402}$ & 90.2 & 2.7 & 89 \\
\hline$\frac{(\mathrm{L}+) \text { Vibrio A8694 }}{(\mathrm{L}+) \text { Vibrio B3547 }}$ & 89.7 & 3.2 & 90 \\
\hline$\frac{(\mathrm{L}+) \text { Vibrio } \mathrm{A} 8694}{(\mathrm{~L}+) \text { Vibrio } \mathrm{C} 7127}$ & 93.2 & 0.2 & 94 \\
\hline$\frac{(\mathrm{L}+) \text { Vibrio } \mathrm{A} 8694}{(\mathrm{~L}+) \text { Vibrio } \mathrm{C} 7684}$ & 92.2 & 0.8 & 86 \\
\hline$\frac{(\mathrm{L}+) \text { Vibrio } \mathrm{A} 8694}{(\mathrm{~L}+) \text { Vibrio } \mathrm{C} 8806}$ & 90.7 & 2.2 & 87 \\
\hline$\frac{(\mathrm{L}+) \text { Vibrio A8694 }}{\text { Vibrio alginolyticus }^{\text {ATCC } 17749}}$ & 78.1 & 14.0 & 24 \\
\hline$\frac{(\mathrm{L}+) \text { Vibrio } \mathrm{A} 8694}{\text { Vibrio alginolyticus } \mathrm{C} 6814}$ & 75.8 & 16.9 & 43 \\
\hline$\frac{(\mathrm{L}+) \text { Vibrio A8694 }}{\text { Vibrio parahaemolyticus ATCC } 17802}$ & 76.9 & 15.2 & 46 \\
\hline$\frac{(\mathrm{L}+) \text { Vibrio A8694 }}{\text { Vibrio parahaemolyticus } \mathrm{A} 8633}$ & 74.9 & 18.0 & 36 \\
\hline$\frac{(\mathrm{L}+) \text { Vibrio } \mathrm{A} 8694}{\text { Vibrio cholerae } 5540-70}$ & 72.0 & 20.9 & 16 \\
\hline$\frac{(\mathrm{L}+) \text { Vibrio A8694 }}{\text { Vibrio cholerae (El Tor) 1320-72 }}$ & 70.6 & 22.3 & 17 \\
\hline$\frac{(\mathrm{L}+) \text { Vibrio A8694 }}{\text { Vibrio cholerae (non-aggl) 1845-73 }}$ & 76.1 & 16.6 & 27 \\
\hline
\end{tabular}

tested were selected from widely different sources (Table 1), the group was genetically homogeneous. The strains also were alike morphologically (gram-negative rods, motile with a single polar flagellum) and biochemically (oxidase positive; indole positive; nitrate positive; proteolytic; MacConkey positive; urease negative; VP negative; lysine positive; arginine negative; fermenting glucose, lactose, and maltose; and requiring 0.5 to $6.0 \% \mathrm{NaCl}$ in growth medium).

The $\mathrm{G}+\mathrm{C}$ content range of 50 to $53 \mathrm{~mol} \%$ for this new species is somewhat high for the genus Vibrio (limits: 40 to $50 \mathrm{~mol} \% \mathrm{G}+\mathrm{C}$ [6]). The fact that the experiment was done with the "batch" HA procedure, in which the binding of DNA to HA could delay elution of single-stranded DNA at the precise temperature of disassociation, could account for the higher-than-expected val- ues obtained. Had the experiment been performed with DNA strands free in solution during heating, a somewhat lower $T_{m}$ value (and therefore a lower $\mathrm{G}+\mathrm{C}$ ratio) might have been obtained. To verify the values we obtained, $\mathrm{G}+\mathrm{C}$ determinations should be made by other means.

With these experiments, we intended to determine genetically the degree of relationship between the $(\mathrm{L}+)$ Vibrio and $V$. alginolyticus and $V$. parahaemolyticus, to which species it seemed to be closely related biochemically. We did not attempt to examine the position of $(\mathrm{L}+)$ Vibrio relative to other recognized species in the genus, i.e., $V$. anguillarum, $V$. fischeri, and $V$. costicola (9). Suffice it to say that the $(\mathrm{L}+)$ Vibrio phenotypically seems even less closely related to these vibrios than to $V$. alginolyticus and to $V$. parahaemolyticus. 


\section{ACKNOWLEDGMENTS}

We thank D. J. Brenner for his guidance, for certain deoxyribonucleic acid preparations, and for the use of his laboratory facilities in these experiments; also we are indebted to Dannie G. Hollis and R. E. Weaver for their help and advice.

\section{REPRINT REQUESTS}

Address reprint requests to: Mr. Arnold G. Steigerwalt, Center for Disease Control, Atlanta, GA 30333.

\section{LITERATURE CITED}

1. Bautz, E. K. F. 1965. Evolutionary aspects of the distribution of nucleotides in DNA and RNA, p. 419-433. In V. Bryson and H. J. Vogel (ed.), Evolving genes and proteins. Academic Press Inc., New York.

2. Brenner, D. J., G. R. Fanning, K. E. Johnson, R. V. Citarella, and S. Falkow. 1969. Polynucleotide sequence relationships among members of Enterobacteriaceae. J. Bacteriol. 98:637-650.

3. Brenner, D. J., G. R. Fanning, A. Rake, and K. E. Johnson. 1969. A batch procedure for thermal elution of DNA from hydroxyapatite. Anal. Biochem. 28:447459.

4. Citarella, R. J., and R. R. Colwell. 1970. Polyphasic taxonomy of the genus Vibrio: polynucleotide sequence relationships among selected Vibrio species. J. Bacteriol. 104:434-442.

5. Hollis, D. G., R. E. Weaver, C. N. Baker, and C. Thornsberry. 1976. A halophilic Vibrio species isolated from blood cultures. J. Clin. Microbiol. 3:425431.

6. Hugh, R., and R. Sakazaki. 1972. Minimal characteristics for the genus Vibrio. Public Health Lab. 30:133137.

7. Marmur, J., and P. Doty. 1959. Heterogeneity in deoxyribonucleic acids. I. Dependence on composition of the configurational stability of deoxyribonucleic acids. Nature (London) 183:1427-1429.

8. Marmur, J., and P. Doty. 1962. Determination of the base composition of deoxyribonucleic acid from its thermal denaturation temperature. J. Mol. Biol. 5:109-118.

9. Shewan, J. M., and M. Véron. 1974. Genus I. Vibrio Pacini 1854, 411, p. 340-345. In R. E. Buchanan and N. E. Gibbons (ed.), Bergey's manual of determinative bacteriology, 8th ed. The Williams \& Wilkins Co., Baltimore.

10. Rubin, S. J., and R. C. Tilton. 1975. Isolation of Vibrio alginolyticus from wound infections. J. Clin. Microbiol. 2:556-558. 